\title{
Association of 'Candidatus Liberibacter solanacearum' with Zebra Chip Disease of Potato Established by Graft and Psyllid Transmission, Electron Microscopy, and PCR
}

\author{
G. A. Secor and V. V. Rivera, Department of Plant Pathology, North Dakota State University, Fargo 58105, USA; \\ J. A. Abad, USDA, APHIS, Beltsville, MD 20705, USA; I.-M. Lee, USDA, ARS, Plant Molecular Laboratory, \\ Beltsville, MD 20705, USA; G. R. G. Clover and L. W. Liefting, Plant Health and Environment Laboratory, MAF \\ Biosecurity, Auckland 1140, New Zealand; and X. Li and S. H. De Boer, Charlottetown Laboratory, CFIA, PEI C1A \\ 5T1, Canada
}

\begin{abstract}
Secor, G. A., Rivera, V. V., Abad, J. A., Lee, I.-M., Clover, G. R. G., Liefting, L. W., Li, X., and De Boer, S. H. 2009. Association of 'Candidatus Liberibacter solanacearum' with zebra chip disease of potato established by graft and psyllid transmission, electron microscopy, and PCR. Plant Dis. 93:574-583.

A new disease of potatoes, tentatively named zebra chip (ZC) because of the intermittent dark and light symptom pattern in affected tubers which is enhanced by frying, was first found in Mexico in 1994 and in the southwestern United States in 2000. The disease can cause severe economic losses in all market classes of potatoes. The cause of $\mathrm{ZC}$ has been elusive, and only recently has been associated with 'Candidatus Liberibacter' sp. Field samples of potato plants were collected from several locations in the United States, Mexico, and Guatemala to determine transmission to potato and tomato by grafting of ZC-infected scions and psyllid feeding. The disease was successfully transmitted, through up to three generations, by sequential top- and side-grafting ZC-infection scions to several potato cultivars and to tomato. The disease was also successfully transmitted to potato and tomato plants in greenhouse experiments by potato psyllids collected from potato plants naturally affected with ZC. Transmission electron microscopic observation of ZC-affected tissues revealed the presence of bacteria-like organisms (BLOs) in the phloem of potato and tomato plants inoculated by grafting and psyllid feeding. The BLOs were morphologically similar in appearance to BLOs associated with other plant diseases. Polymerase chain reaction (PCR) amplified 16S rDNA sequences from samples representing different geographic areas, including the United States, Mexico, and Guatemala, were almost identical to the 16S rDNA of ' $\mathrm{Ca}$. L. solanacearum' previously reported from solanaceous plants in New Zealand and the United States. Two subclades were identified that differed in two single base-pair substitutions. New specific primers along with an innovative rapid PCR were developed. This test allows the detection of the bacteria in less than 90 min. These data confirm the association of ' $\mathrm{Ca}$. L. solanacearum' with potatoes affected by ZC in the United States, Mexico, and Guatemala.
\end{abstract}

A new disease of potato exhibiting symptoms similar to potato purple top (PPT) and psyllid yellows (PY) was first identified in commercial potato fields in Texas and Mexico in 1994 (35). This disease complex has been tentatively named zebra chip (ZC) because of the severe dark and light striped symptom pattern in both raw tubers and chips made from diseased tubers. ZC has been found in several potato producing areas in the United States since 2000, affecting all cultivars of tablestock and processing potatoes and causing

Corresponding author: Gary A. Secor

E-mail: gary.secor@ndsu.edu

Accepted for publication 9 February 2009

doi:10.1094/PDIS-93-6-0574

(C) 2009 The American Phytopathological Society severe losses in recent years. Infected potato plants exhibit a wide range of symptoms similar to PPT and PY, including chlorosis, twisted stems with a zigzag appearance, swollen nodes, aerial tubers, vascular discoloration, and leaf scorching and wilting. The primary tuber symptom is extensive brown coloration of the vascular ring and medullary rays throughout the entire length of the tuber. This latter symptom is diagnostic and separates it from other known diseases of potato. Tubers affected by ZC rarely sprout, and if they do, often produce hair sprouts and weak plants.

Like PPT and PY, ZC symptoms in potato are characteristic of diseases in which transport of assimilates in phloem vessels is compromised. Although misshapen tubers and roughened periderm are associated with PY (6), neither PPT nor PY normally induces tuber necrosis, which is characteristic of ZC. In some instances, PPT may cause mild discoloration of the vascular tissues on the stem end of the tubers from affected plants, and may be confused with ZC, but PPT discoloration does not penetrate as deeply into the tuber flesh as ZC symptoms. Consequently, ZC is considered to be a different disease from PPT and PY. PPT has been recognized for decades in Canada and the United States at low levels, and is a limiting factor for potato production in Mexico $(4,18)$. Although PY was described in the United States about 80 years ago, and while it sometimes also causes severe crop losses, very little research has been conducted on the disease $(2,31)$. Several phytoplasmas have been identified that can cause PPT symptoms, including the clover proliferation phytoplasma $(7,16)$, the aster yellows phytoplasma $(34,38)$, and 'Candidatus Phytoplasma americanum' (15,34). A new bacterial species tentatively designated 'Candidatus Liberibacter psyllaurous' was recently reported to be associated with PY (11).

ZC was first documented in potato fields around Saltillo, Mexico in 1994 (35), where it is referred to as "papa manchada" (meaning stained potato), and subsequently was observed in commercial potato fields in other Mexican states. In the United States, ZC was first noted in the area around Pearsall, TX, and since 2000 it has occurred in California, Colorado, Kansas, Nebraska, Nevada, and New Mexico. It is also present in Guatemala, where the disease is known as "papa rayada" (meaning striped potato). The incidence and severity of disease varies from year to year, but wherever it occurs, it is accompanied by serious economic consequences, since potatoes affected with ZC are unmarketable for both fresh market sales and processing into food products such as chips. In years of severe infection, up to $80 \%$ of fields may be affected in a given potato-growing region.

There is good evidence that the ZC disease agent, like PY, is vectored by the potato psyllid, Bactericera cockerelli Sulc $(25,26)$. Plants protected from insects in 
greenhouses or screened cages in the field remained free of $\mathrm{ZC}$ symptoms, while a high percentage of plants exposed to insect feeding in the field developed typical symptoms. Moreover, potato plants held in an insect-proof greenhouse and exposed to infectious psyllids developed ZC symptoms. Association of psyllids with the occurrence of ZC symptoms is also known from field observations (25), and psyllid control strategies mitigate the incidence of the disease (10).

The identity of the etiologic agent of ZC has been elusive. Initially, phytoplasmas were suspected on the basis of symptomology similar to PPT, but the presence of phytoplasma could not be consistently confirmed by polymerase chain reaction (PCR) using generic phytoplasma primers (33). Subsequently, it was suggested on the basis of preliminary electron microscopic observations and molecular work that $\mathrm{ZC}$ might be caused by a bacterium-like organism (BLO) $(8,19,36)$. Several other similar plant diseases were initially also described as having a BLO etiology and include yellow vine of cucurbit (30), marginal chlorosis of strawberry (42), "basses richesses" of sugar beet (37), and citrus greening (huanglongbing) (12,40). The BLOs are phloem-limited alpha or gamma proteobacteria vectored by plant-sap feeding insects. Some BLOs have now been named and include Serratia marcescens, 'Candidatus Phlomobacter fragariae', 'Candidatus Liberibacter asiaticus', ' $\mathrm{Ca}$. Liberibacter africanus', and ' $\mathrm{Ca}$. Liberibacter americanus'.

Recently, Liefting et al. $(21,23)$ discovered that a new disease in tomato and pepper in New Zealand was caused by ' $\mathrm{Ca}$. Liberibacter solanacearum'. They modified liberibacter primers used for detection of citrus liberibacter by PCR and found that the test also amplified DNA extracted from field-grown potatoes in New Zealand with symptoms resembling ZC, suggesting a similar etiology (20). Subsequently, ' $C a$. L. solanacearum' was also detected in tamarillo (Solanum betaceum) and cape gooseberry (Physalis peruviania) (22). In July 2008, we used the primers developed by Liefting et al. (21) to confirm for the first time that ' $\mathrm{Ca}$. L. solanacearum' was also associated with zebra chip in potato samples collected in Texas (1). At about the same time, Hansen et al. (11) published on an association of ' $\mathrm{Ca}$. Liberibacter psyllaurous' with PY in tomato and potato in the United States.

In this paper we describe the association of ' $C a$. L. solanacearum' with ZC as shown by electron microscopy and molecular characterization of DNA fragments specifically amplified from symptomatic potato and tomato plants infected by graft and psyllid transmission from potato plants with ZC symptoms. Sequence data of $16 \mathrm{~S}$ DNA from ZC-infected potato is compared with comparable sequences of other ' $\mathrm{Ca}$. Liberibacter' spp. to establish its relative taxonomic position.

\section{MATERIALS AND METHODS}

Collection of field potato samples. Potato stems with associated leaves used in this study were collected from potato plants with ZC symptoms in commercial potato fields in the United States, Mexico, and Guatemala from 2005 to 2008. ZC disease was verified by the presence of foliar symptoms and characteristic necrotic medullary ray symptoms in tubers.

Graft transmission procedure. Buds and growing points from $\mathrm{ZC}$ stems were used for grafting to potato cvs. Atlantic, Shepody, Russet Norkotah, and Frontier Russet and tomato cv. Roma in the greenhouse to confirm the presence of the ZC agent. Wedge-shaped scions containing terminal or axillary leaf buds cut from field-grown stems with ZC symptoms or grown from symptomatic tubers in the greenhouse were top- or side-grafted onto greenhouse-grown potato or tomato plants (29). Grafts were bound with grafting tape, and the plants were covered with clear plastic bags for 2 to 7 days to maintain humidity at greenhouse temperatures rang-

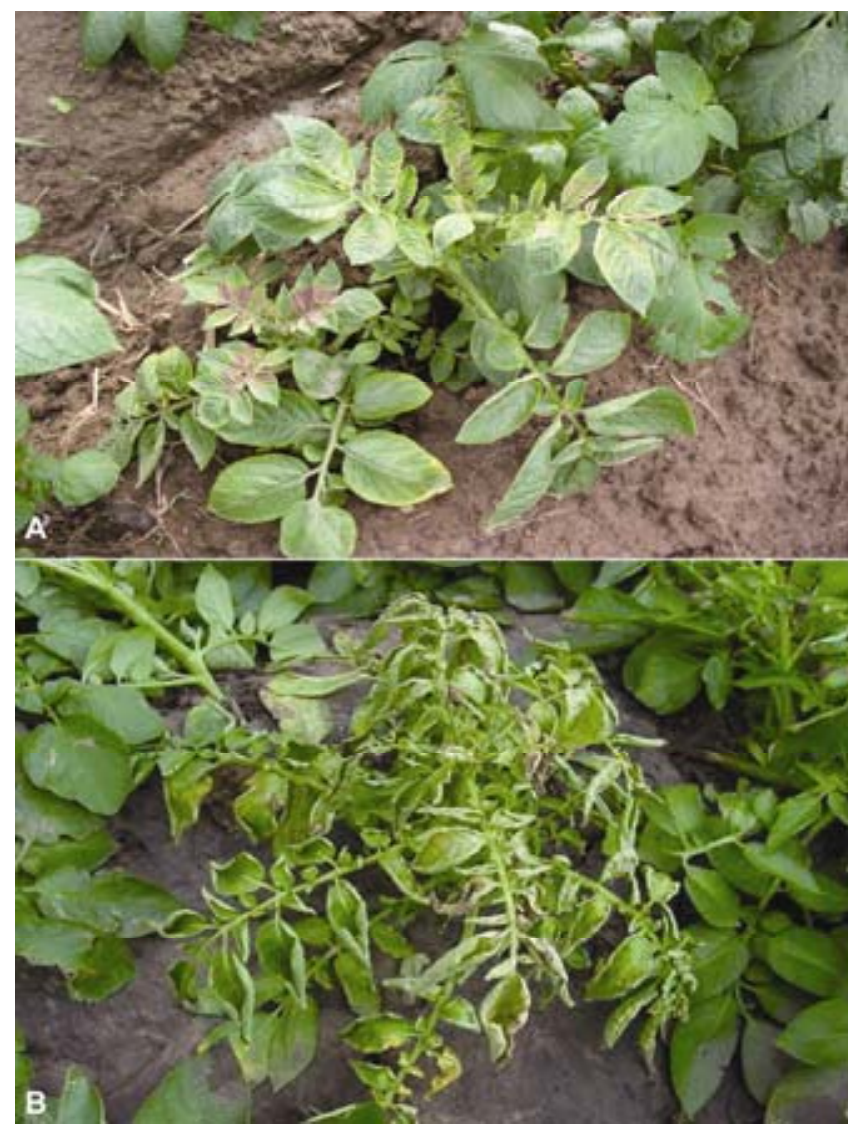

Fig. 1. Foliar symptoms of zebra chip disease in field-grown potato in Pearsall, TX showing A, chlorosis and deformation, and B, leaf curling and scorch.

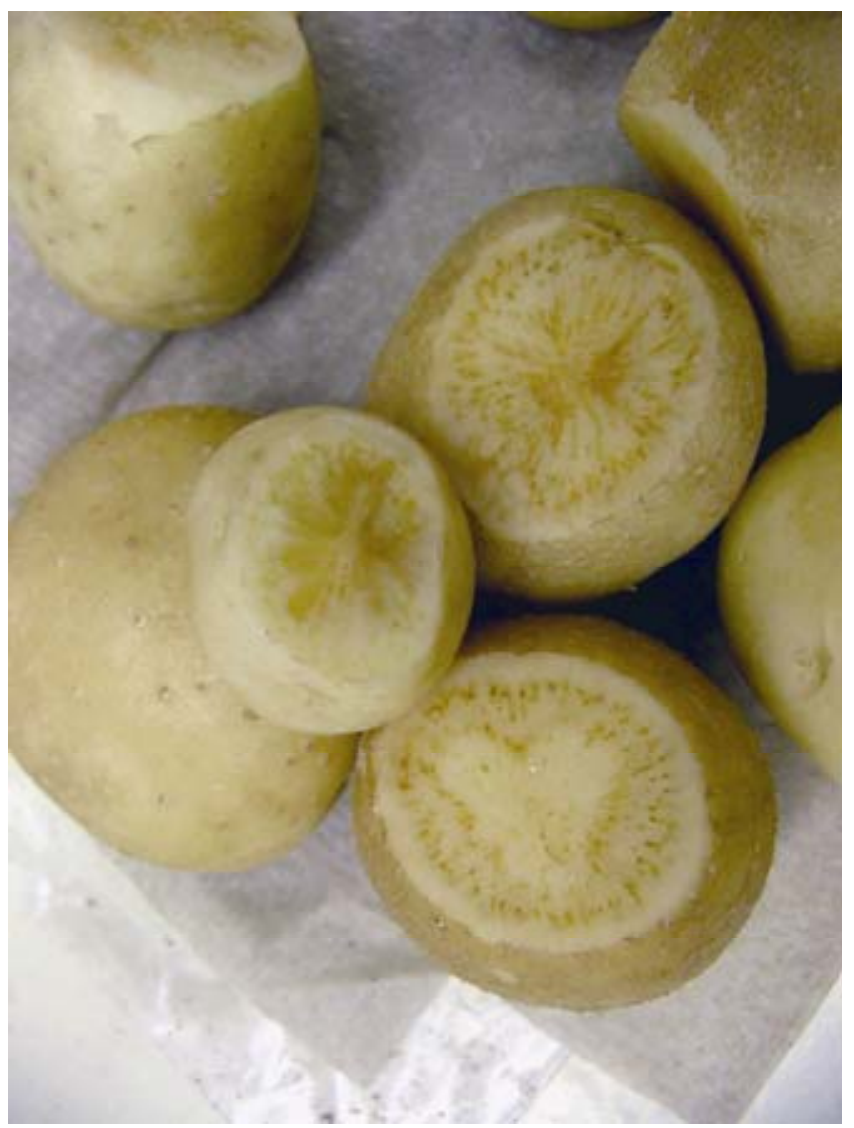

Fig. 2. Characteristic symptom of zebra chip disease in field-grown tubers showing necrotic browning in medullary ray tissue throughout the tuber. 
ing from 20 to $30^{\circ} \mathrm{C}$. Plants were observed weekly for foliar symptoms of zebra chip disease. Symptomatic plants were sampled when symptoms developed and tubers (if any) were harvested at senescence. Harvested tubers were cut to determine the presence of internal discoloration confirming ZC infection and saved for further testing. Infection of tomato plants was scored on the basis of foliar symptoms only.

Psyllid transmission experiments. Potato leaves naturally infested with late instar potato psyllid nymphs were collected from potato plants (cv. Red LaSoda) with visible $\mathrm{ZC}$ tuber symptoms in a commercial potato field near Pearsall, TX. Psyllid-infested leaves were hand-carried and transferred to healthy potato and tomato plants in greenhouse cages the day after collection. The cages were wooden frames covered with insect-proof tuelling fabric with enough room to accommodate six plants. Transfer of psyllids collected from the field to caged plants was done by examining infested leaves with a dissecting microscope to locate and identify individual psyllid nymphs and to ensure freedom from contaminating insects. Individual psyllid nymphs (usually stages 3 to 5 , often with visible wingpads) were collected by punching a $5-\mathrm{mm}$ leaf disk with the attached nymph and storing in a plastic petri dish until transfer. Psyllid-containing disks were transferred to cages and distributed among the potato and tomato plants inside each cage. Each cage contained four potato plants and two tomato plants. Potato plants used were cv. Atlantic grown from pathogen-free minitubers (Sklarczyk Seed Farms, Johannesburg, MI); tomato plants (cv. Roma) were grown from seed and transplanted into individual pots at the three- to four-leaf stage. All plants were grown in pots of Sunshine Mix (Sun Gro Horticulture, Vancouver, BC). All work was conducted in a single isolated greenhouse room.

Approximately 10 to 20 psyllid nymphinfested potato-leaflet disks (each containing one psyllid nymph) from ZC plants collected were transferred to each cage. Cages of plants without psyllid introductions were used as controls. The infested plants were maintained at $30^{\circ} \mathrm{C}$ with supplemental lighting and watered as necessary from the top without opening the cage door.

Psyllids were allowed to feed and reproduce on the ZC-infected plants in the greenhouse and then were transferred twice to new plants in cages as described above. Most transfers consisted of adults and nymphs, but individual transfers of adults, nymphs, and eggs were also made. Confirmation of $\mathrm{ZC}$ infection of potatoes was evaluated by cutting progeny tubers from the plants and observing medullary ray discoloration.

Transmission electron microscopy (TEM). Various tissues (stem, root, stolon) from potato plants with $\mathrm{ZC}$ symptoms collected from commercial potato fields near Pearsall, TX in 2001 were used for preliminary TEM studies. Later, petiole sections were collected from symptomatic tomato plants in the greenhouse that had been top grafted with $\mathrm{ZC}$ potato terminal buds as described or from tomato plants that had been exposed to psyllids in transmission trials.

Specimens for examination by TEM were fixed in $2.5 \%$ glutaraldehyde in 0.1 M sodium phosphate buffer, pH 7.35 (Tousimis Research Corporation, Rockville, MD) for at least $2 \mathrm{~h}$ in the refrigerator. They were rinsed in sodium phosphate buffer $(\mathrm{pH} 7.35)$ and then placed in $2 \%$ osmium tetroxide in buffer for $2 \mathrm{~h}$ at room temperature. Following dehydration in a graded acetone series, samples were embedded in Epon-Araldite-DDSA and sectioned at $60 \mathrm{~nm}$ thickness. Sections on grids were stained with lead citrate for 2.5 min before observation on a JEOL JEM100CX II electron microscope.

DNA extraction and PCR procedure. Protocols for DNA extraction from potato tubers, roots, and foliage, and from psyllids differed among the laboratories participating in this study. In the Charlottetown lab, potato tuber or stem tissue was macerated in BioReba sample bags in TE buffer and DNA prepared with a Kingfisher extractor (Thermo Fisher Scientific Inc., Waltham, MA) using Magnesil KF Genomic System reagents (Promega Corp., Madison, WI) following the supplier's instructions. In the Beltsville lab, DNA was extracted from $200 \mathrm{mg}$ of tissue using the DNeasy Plant Mini Kit (Qiagen, Valencia, CA) or the FastPrep extraction system (MP Biomedical, Solon, OH) following the respective manufacturer's protocols. The concentration and quality of total DNA was estimated with a microvolume spectrophotometer (NanoDrop Technologies, Wilmington, DE).

PCR using liberibacter-specific primers was carried out according to the protocol and conditions recommended by Liefting et al. (21). The PCR amplification was performed in 25:1 volumes with premixed reagents (Clontech, Mountain View, CA) and $0.25: \mathrm{M}$ of primers $\mathrm{OA} 2$ and $\mathrm{O} 12 \mathrm{c}$ with the following temperature cycling conditions: an initial cycle at $94^{\circ} \mathrm{C}$ for $5 \mathrm{~min}$, followed by 40 cycles of $94^{\circ} \mathrm{C}$ for $30 \mathrm{~s}$, $65^{\circ} \mathrm{C}$ for $30 \mathrm{~s}$, and $72^{\circ} \mathrm{C}$ for $1 \mathrm{~min}$, plus a final cycle of $10 \mathrm{~min}$ at $72^{\circ} \mathrm{C}$. Aliquots of 5 $: 1 \mathrm{PCR}$ product were electrophoresed in $1 \%$ agarose gels $(0.5 \times \mathrm{TBE})$ containing ethidium bromide. Alternatively, PCR tests used forward primer CLi.po.F and reverse primer O12c. Forward primer CLi.po.F (5'TACGCCCTGAGAAGGGGAAAGATT-3') was empirically designed from the $16 \mathrm{~S}$ rDNA sequences in the NCBI GenBank for 'Ca. L. asiaticus', ' $C a$. L. africanus', ' $C a$. L. americanus', and the 'Ca. L. solanacearum' from ZC-infected potato in New Zea- land (accession number EU834130) and the United States (accession numbers EU884128 and EU884129), and tested in silico for specificity in this study. This primer pair was used at 0.2:M each in 25:1 reactions using the SpeedSTAR DNA polymerase kit (Takara Bio, Madison, WI). Temperature cycling parameters were $94^{\circ} \mathrm{C}$ for $1 \mathrm{~min}$ followed by 30 cycles of $95^{\circ} \mathrm{C}$ for $5 \mathrm{~s}$ and $68^{\circ} \mathrm{C}$ for $30 \mathrm{~s}$. For some experiments, other polymerases, including Taq Gold (Applied Biosystems, Foster City, CA) and Platinum Taq (Invitrogen, Carlsbad, CA), were used with corresponding buffers.

Sequencing and alignments. PCR products were gel-purified as per kit instructions (MoBio Laboratories, Inc., Carlsbad, CA) and sequenced directly or cloned into the pGEM-T vector prior to sequencing by McLab Inc. (San Francisco, CA) or Ottawa Health Research Institute, Canada. Proofread sequencing data were blasted against 16S rRNA sequences in GenBank using Blastn.

Nucleotide consensus sequences of the amplified liberibacter 16S rDNA segments amplified from potato samples collected in Texas, California, Colorado, Mexico, and Guatemala were assembled using Vector NTi (InforMax Inc., Frederick, MD). The sequences reported in this study have been submitted to GenBank (accession nos. EU884128, EU884129, and FJ395203-FJ395219). Selected sequences of the different ' $\mathrm{Ca}$. Liberibacter' spp. from the NCBI GenBank were obtained and aligned using Clustal $\mathrm{X}$ version 1.81 (41). Neighbor-joining (NJ) phylograms, based on the Kimura twoparameter distance matrix with complete deletion as gap treatment were generated by MEGA 2.1 (14). Bootstrap confidence limits were derived by 1,000 replicates. The tree was estimated with neighborjoining algorithms and exported via TREEVIEW (28).

\section{RESULTS}

Detection in field samples. Potato plants collected from fields in the United States, Mexico, and Guatemala during 2005 to 2007 all displayed foliar symptoms of ZC including leaf yellowing, mild purpling, leaf curling, and scorch (Fig. 1). Progeny tubers on these plants displayed symptoms ranging from mild to severe brown discoloration of the medullary rays (Fig. 2). All samples tested negative for phytoplasmas using nested PCR with the universal primer pair P1/P7 (32) followed by F2n/R2 (17) (data not shown). However, a 1,160-bp amplicon was generated by PCR using primer pair OA2/O12c from DNA templates extracted from symptomatic potato foliage and tubers of the commercial potato crops. Although not every sample generated amplified product, a positive PCR test was recorded in some samples from each of the three countries 
during each year that samples were available (Table 1). The possibility that negative PCR reactions were due to co-extracted PCR inhibitors in the DNA templates was not investigated.

A new forward primer, CLi.po.F, developed to differentiate potato strains of liberibacter from those infecting citrus, amplified a 1,070-bp fragment from ZCinfected potato tissue in conjunction with the O12c primer (Fig. 3).

Graft transmission. Although fieldgrown tubers with ZC symptoms collected in Texas sprouted poorly, about $20 \%$ percent of the tubers did sprout and produced plants under greenhouse conditions. These plants were weak, stunted, and displayed foliar symptoms associated with ZC such as twisted stems with swollen nodes and misshapen leaves with purple coloration. Grafting scions from these plants to 4week-old greenhouse-grown potato plants (cv. Atlantic, Frontier Russet, Shepody, and Russet Norkotah) resulted in purpling and narrowing of apical leaves and stiffening and/or chlorosis of older leaves followed by leaf necrosis and sometimes death of the plant (Fig. 4A, Table 2). Foliar symptoms were accompanied by inhibition of the root system which probably accounted for some of the nutritional deficiency-like symptoms expressed by infected plants. Diseased plants produced few progeny tubers.

Plants of cv. Frontier Russet responded to ZC graft inoculation by developing symptoms 7 days earlier than other potato cultivars tested and were dead within 6 weeks. Plants of cvs. Shepody and Atlantic survived to produce small tubers, all of which had internal symptoms of ZC upon harvest. A second generation of cv. Atlantic plants grafted with scions from the first generation of grafted plants also developed symptoms of ZC. Stem and tuber tissues from the first and second generation of grafted plants yielded positive results in the liberibacter-specific PCR test (Table 2).
Generally a greater amount of PCR product was amplified from stem tissue compared to tuber tissue.

Grafting of scions from ZC-infected potato into 3- to 4-week-old tomato plants (cv. Roma) resulted in symptoms developing within 4 to 6 weeks (Fig. 4B). Symptoms included stunting with a bunchy growth habit, purpling of leaves and leaflet malformation, and size reduction. Tissue samples from these plants were also positive in the liberibacter-specific PCR test (Table 1).

Psyllid transmission. A preliminary trial in 2006 demonstrated transmission of ZC by psyllids collected from ZC potato plants to healthy plants in the greenhouse (data not shown). Consequently, a controlled greenhouse study was conducted in 2008 to verify the previous results. About $25 \%$ of the psyllids collected in fields with ZC-infected potatoes tested positive for liberibacter by PCR. ZC-like symptoms developed in the foliage of potato plants 6 weeks after feeding by psyllids collected in commercial ZC-infected potato fields in Texas (Table 3). Although a significant number of plants to which psyllids had been transferred failed to produce progeny tubers, all those that did and were populated with infectious psyllids developed ZC tuber symptoms. In a few cages, psyllid colonies failed to establish and recipient plants remained healthy (data not shown). ZC disease did not develop on any of the plants in one cage although the psyllid population thrived, and also did not develop in control plants in cages in which no psyllids were introduced (Table 3 ).

The ZC disease was transferred from the first generation of plants inoculated by psyllid transmission to a second generation of plants, and presence of liberibacter was confirmed by PCR in the second generation plants (Table 3 ). In a few cases, successful transmission to a third generation was achieved (Table 3). Transmission of ZC by psyllids to tomato was also successful to both a first and second generation of plants and was also confirmed by PCR using liberibacter primers (Table 3). Transmission to a third generation of tomato was unsuccessful.

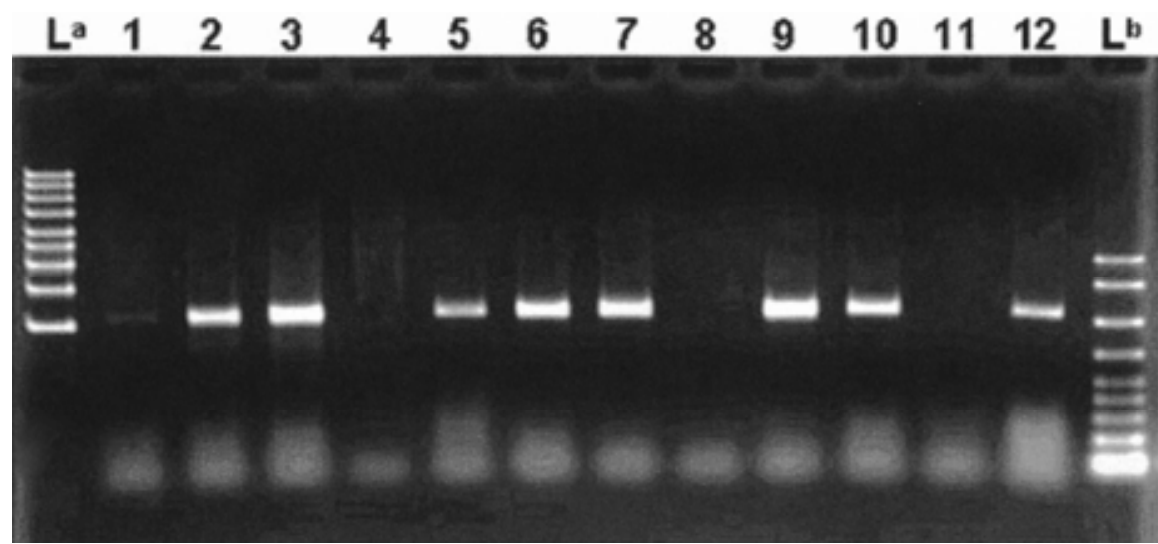

Fig. 3. Gel electrophoretogram of polymerase chain reaction (PCR) products generated using primer pair CLi.po.F/O12c from symptomatic potato tuber (lane 1), roots (lanes 2, 3, 9, and 10), midplant leaf midrib (lane 5), midplant petiole (lane 12), and plant apex (lane 11). Lanes 4 and 8 are from root and leaf midrib, respectively, of healthy plant. Lanes $\mathrm{L}^{\mathrm{a}}$ and $\mathrm{L}^{\mathrm{b}}$ denote 10-bp and 100-bp DNA ladders, respectively.

Table 1. Sample identity and 16s rRNA gene sequence of 'Candidatus Liberibacter solanacearum' subclades amplified by polymerase chain reaction (PCR) from field-infected potato tissue, psyllid-fed greenhouse-grown tomato plants, or psyllids collected from multiple locations during 2005 to 2008

\begin{tabular}{|c|c|c|c|c|c|}
\hline Sample no. & Date collected & Location & Collector & Tissue tested & $\begin{array}{l}\text { Sequence accession } \\
\text { no. (subclade }{ }^{a} \text { ) }\end{array}$ \\
\hline $429-2$ & April 2005 & Pearsall, TX & G. Secor & Leaf & FJ395204(sC2) \\
\hline $432-2$ & April 2005 & Asturias, Guatemala & R. Estrada & Stolon & FJ395205(sC2) \\
\hline $440-1$ & April 2005 & Pearsall, TX & G. Secor & Tuber & FJ395206(sC1) \\
\hline $442-1$ & April 2005 & Edinburg, TX & G. Secor & Stolon & FJ395207(sC2) \\
\hline $443-5$ & April 2005 & Bakersfield, CA & N. Gudmestad & Stolon & FJ395208(sC2) \\
\hline $497-12$ & June 2005 & Olton, TX & N. Gudmestad & Stolon & FJ395209(sC1) \\
\hline $664-0$ & July 2006 & Psyllid transmitted from Pearsall, TX & G. Secor & Tuber & FJ395211(sC1) \\
\hline $667-1$ & July 2006 & Casas Grandes, Mexico & A. Walther & Leaf & FJ395212(sC2) \\
\hline $677-2$ & August 2006 & Saltillo, Mexico & V. Rivera & Leaf & FJ395213(sC2) \\
\hline $677-18$ & August 2006 & Saltillo, Mexico & V. Rivera & Leaf & FJ395214(sC1) \\
\hline $685-1$ & August 2006 & San Luis Valley, CO & J. Gilley & Leaf & $\mathrm{FJ} 395215(\mathrm{sC} 2)$ \\
\hline $728-1$ & February 2007 & Asturias, Guatemala & R. Estrada & Stolon & FJ395216(sC1) \\
\hline $743-2$ & April 2007 & Pearsall, TX & P. Lummus & Psyllid & FJ395217(sC1) \\
\hline $802-1$ & April 2008 & Psyllid transmitted from Pearsall, TX & G. Secor & Tuber & FJ395218(sC2) \\
\hline $802-2$ & April 2008 & Psyllid transmitted from Pearsall, TX & G. Secor & Tomato & FJ395219(sC2) \\
\hline
\end{tabular}

${ }^{a}$ Sequence subclade 1 (sC1) denotes identity with sequence of tomato/pepper ' $\mathrm{Ca}$. Liberibacter solanacearum' detected in New Zealand; sequence subclade (sC2) denotes two-base difference with New Zealand liberibacter. 
TEM studies. Because of the disintegration and poor condition of ZC-affected potato tissues (stems, roots, petioles) and the difficulty of fixation due to the presence of starch, it was difficult to find structures representative of BLOs in thin sections of potato plants with ZC directly from the field using TEM. However, BLOs were observed in transverse sections of stem phloem from some potato plants with $\mathrm{ZC}$ collected from the field in 2001 (Fig. 5A) and in 2008 (Fig. 5B). We discovered that tomato plants were more suitable than potato for TEM studies, and therefore, these were used for additional TEM studies on the ZC agent. TEM of tomato petioles inoculated with $\mathrm{ZC}$ by either grafting or psyllid transmission revealed the presence of BLOs in phloem sieve elements but not in associated companion or mesophyll cells (Fig. 6). The BLOs were pleomorphic in shape and had a weakly stained central area. Individual BLOs were surrounded by an electron dense cell wall separate from the cytoplasmic membrane which was slightly rippled, wrinkled, or uneven (Figs. 5 and 6).

Sequence analyses. After correction by visual proofreading, DNA sequences of 17 PCR amplicons representing samples from different geographic areas (United States, Mexico, and Guatemala) collected at dif- ferent times and from different plant parts (leaves, stolons, and tubers), using either primer set, were almost identical with ' $\mathrm{Ca}$. L. solanacearum' isolated from potato in New Zealand (e.g., NZ082991) and 'Ca. L. psyllaurous' (e.g., EU12559) associated with tomato and potato yellows in California (Fig. 7). Each sequence, including those plants to which ZC had been transmitted by grafting or psyllid feeding, had a perfect match to one of two reference sequences that differed in only two base pairs (Table 1). In comparison to other liberibacters, the $\mathrm{ZC}$ sequences showed 94 to $97 \%$ similarity with GenBank sequences of 'Ca. L. asiaticus' (e.g., EU130555), 'Ca. L. africanus' (e.g., AF137368), and 'Ca. L. americanus' (e.g., AY742824) (Fig. 7). The next most closely similar bacterial genus was Sinorhizobium (e.g., AM181752) with a shared 16S rRNA gene homology of about $89 \%$.

The phylogenetic analysis based on sequences of the $16 \mathrm{~S}$ rDNA fragment ob-

Table 2. Graft transmission of zebra chip (ZC) disease to healthy potato plants in greenhouse conditions based on symptom development and reaction with liberibacter-specific polymerase chain reaction (PCR) assay

\begin{tabular}{|c|c|c|c|c|c|}
\hline \multirow[b]{2}{*}{ Exp. } & \multirow[b]{2}{*}{ Source plant } & \multirow[b]{2}{*}{ Recipient plant } & \multicolumn{3}{|c|}{ ZC symptoms } \\
\hline & & & Foliage & Tuber & PCR \\
\hline 1 & Stem cv. Atlantic from Texas & cv. Atlantic & + & + & + \\
\hline 2 & Recipient from exp. 1 & cv. Atlantic & + & + & + \\
\hline $2 \mathrm{~B}$ & Recipient from exp. 2 & cv. Shepody & + & + & + \\
\hline $2 \mathrm{C}$ & Recipient from exp. 2 & cv. Frontier Russet & + & + & + \\
\hline 3 & $\begin{array}{l}\text { Healthy cv. Atlantic, greenhouse } \\
\text { grown }\end{array}$ & cv. Atlantic & - & - & - \\
\hline 4 & $\begin{array}{l}\text { Plant from ZC-infected tuber } \\
\text { cv. Atlantic from Texas }\end{array}$ & cv. Shepody & + & + & + \\
\hline 4B & Recipient from exp. 4 & cv. Russet Norkotah & + & + & + \\
\hline 5 & Recipient from exp. 4 & cv. Atlantic & + & + & + \\
\hline 6 & $\begin{array}{l}\text { Plant from ZC-infected tuber } \\
\text { cv. Atlantic from Texas }\end{array}$ & cv. Atlantic & + & + & + \\
\hline 7 & Recipient from exp. 6 & cv. Atlantic & + & + & + \\
\hline
\end{tabular}

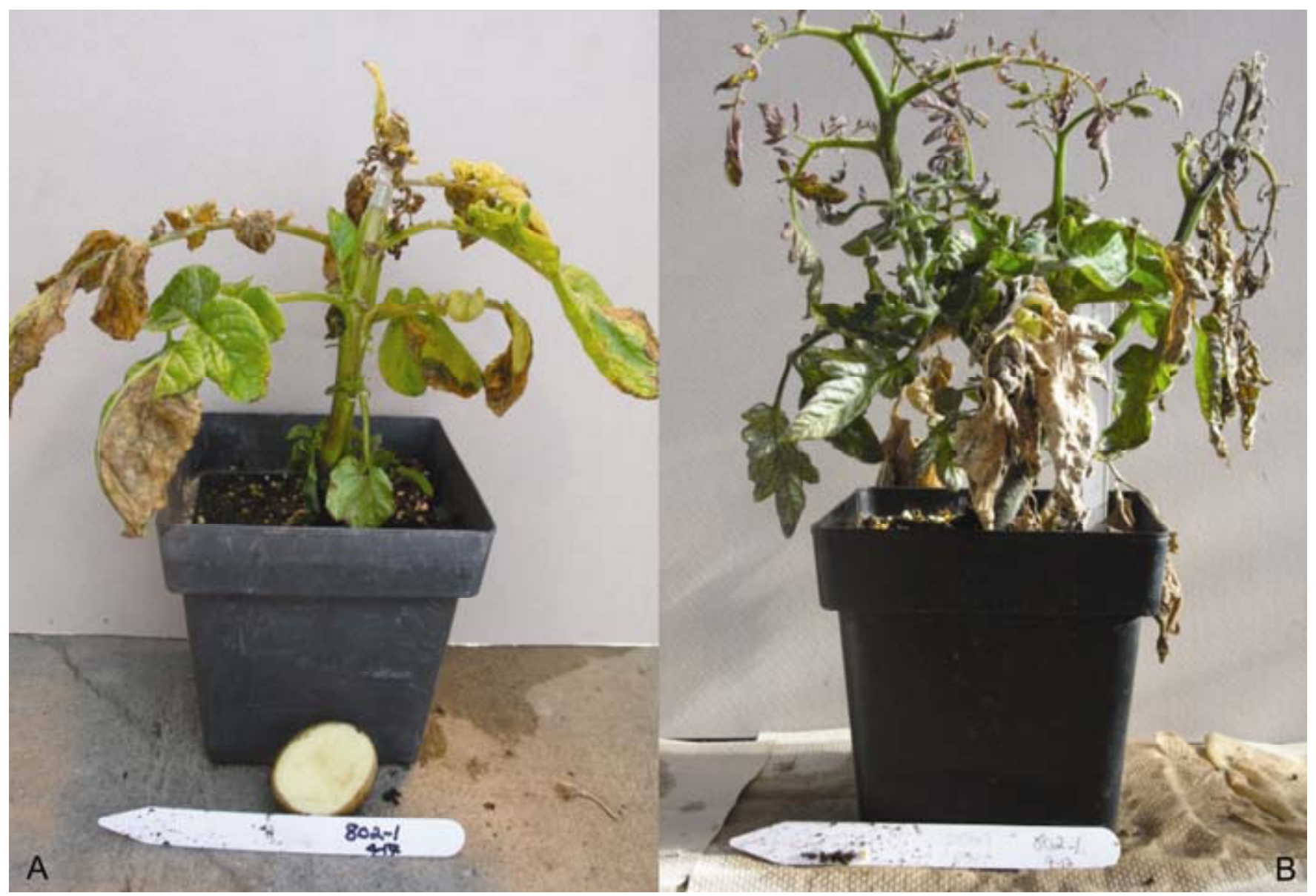

Fig. 4. Severe symptoms expressed in A, Atlantic potato plant, and $\mathbf{B}$, Roma tomato plant following graft inoculation with a scion from a field-grown potato plant with zebra chip from Texas. 
tained in this study shows consistently that all the liberibacters obtained from potatoes and tomatoes belong to the genus ' $\mathrm{Ca}$. Liberibacter'. However, two subclusters were identified among the liberibacter from solanaceous plants due to two base substitutions (Fig. 7).

\section{DISCUSSION}

Our data confirm the association of ' $\mathrm{Ca}$. L. solanacearum' with ZC of potatoes. Symptoms of internal tuber necrosis were consistently observed in progeny tubers produced on plants inoculated with $\mathrm{ZC}$ by both grafting and psyllid feeding, but not in progeny tubers of control plants. Grafting of diseased plant scions to healthy indicator plants is a commonly used method in plant pathology to ascertain the biological nature of nonmechanically transmitted viruses and nonculturable prokaryotes. The repeatedly successful transmission of $\mathrm{ZC}$ to a second generation of grafted potato (Table 1 ) attests to the biological nature of $\mathrm{ZC}$ and eliminated the possibility of the disease being caused by a psyllid toxin as had been speculated upon for the psyllid yellows disease (5).

Our study also confirmed the association between $\mathrm{ZC}$ and the potato psyllid as published recently (25). Not only did psyllids collected from field-grown ZCinfected plants transmit the disease to greenhouse-grown potatoes, but ZC was also transmitted by psyllids from colonies established in the greenhouse and sequentially transferred from ZC-diseased to healthy plants. Although foliar symptoms of ZC were consistently observed in diseased potato plants, only necrotic medullary ray tissue in progeny tubers was considered diagnostic for the disease. Foliar symptoms of a yellows-type disease on tomato after inoculation from ZC-infected potato plants by graft or psyllid transmission were assumed to be due to the $\mathrm{ZC}$ causal agent and in some cases confirmed by a positive PCR test for liberibacter.

TEM revealed the presence of BLOs in graft- and psyllid-inoculated potato plants that developed ZC symptoms as well as tomato plants that developed a yellowstype symptom upon graft and psyllid inoculation from ZC-infected potato. Previ- ously, we had speculated on the basis of electron microscopic data and preliminary molecular test results that BLOs were associated with ZC $(8,19,36)$, but our re-

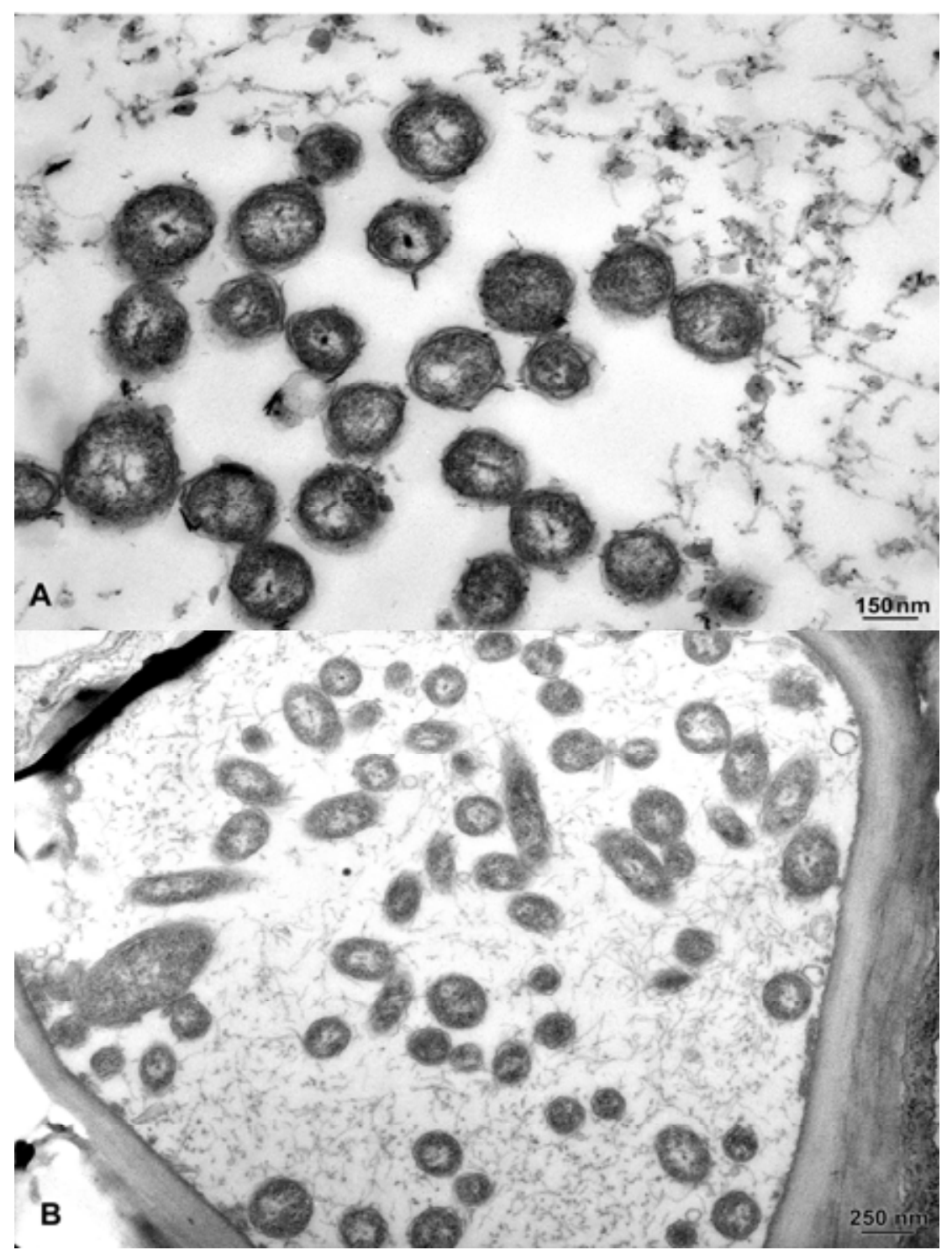

Fig. 5. Transmission electron micrograph of bacteria-like organisms in phloem cells in the stem of $\mathbf{A}$, a field-grown potato plant cv. Atlantic from 2001, and B, a graft-inoculated potato plant cv. Atlantic from 2008 expressing symptoms of the zebra chip disease.

Table 3. Experimental transmission of zebra chip (ZC) disease by psyllids collected from ZC-infected field plants in Pearsall, TX to potato and tomato in greenhouse cages

\begin{tabular}{|c|c|c|c|c|c|c|}
\hline $\begin{array}{l}\text { Psyllid } \\
\text { population }\end{array}$ & Psyllid stage & 1st Recipient plant & Psyllid stage & $\begin{array}{l}\text { 2nd Generation } \\
\text { recipient }\end{array}$ & Psyllid stage & $\begin{array}{l}\text { 3rd Generation } \\
\text { recipient }\end{array}$ \\
\hline 1 & Nymph & Potato $2 / 2^{a}$ & Adult\&nymph & Potato $1 / 1$ & Adult\&nymph & Potato $3 / 4$ \\
\hline \multirow[t]{4}{*}{2} & Nymph & Potato $3 / 3$ & Adult & Potato $1 / 1^{\mathrm{b}}$ & Adult\&nymph & Potato 0/- \\
\hline & & & Adult & Tomato 1/_b & Not continued & $\mathrm{ND}^{\mathrm{c}}$ \\
\hline & & & Nymph & Potato $1 / 1$ & Not continued & ND \\
\hline & & & Egg & Potato $1 / 1$ & Not continued & ND \\
\hline 3 & Nymph & Potato $2 / 2$ & Nymph & Potato $4 / 4$ & Adult\&nymph & Potato $1 / 1$ Tomato $0 /{ }^{\mathrm{d}}$ \\
\hline 4 & Nymph & Potato $3 / 3$ & Adult\&nymph & Potato $1 / 1$ & Adult\&nymph & Potato 0/- \\
\hline 5 & Nymph & Potato $0 / 4$ & Not continued & ND & ND & ND \\
\hline Control 1 & None & Potato $0 / 4$ & Not continued & ND & ND & ND \\
\hline Control 2 & None & Potato $0 / 4$ & Not continued & ND & ND & ND \\
\hline
\end{tabular}

${ }^{a}$ Number of plants with progeny tubers with ZC symptoms/number of plants with progeny tubers; of four plants per trial, some did not produce progeny tubers; ZC determined by observation necrotic medullary ray tissue in cut tubers.

${ }^{\mathrm{b}}$ Presence of ZC-associated liberibacter confirmed by positive polymerase chain reaction (PCR) test for liberibacter (- indicates no tubers).

${ }^{\mathrm{c}}$ Not done.

d PCR test for liberibacter was negative. 
search data are first published here. We also note, however, that transmission electron micrographs remarkably similar to ours showing BLOs in vascular tissue of diseased potatoes were published in Israel over 30 years ago (13). Foliar symptoms of the potato disease in Israel, referred to as leaflet stunt disease, are not inconsistent with those of $\mathrm{ZC}$, although tuber symptoms were not mentioned in the report. Leaflet stunt was also graft transmissible to tomato and occurred naturally in datura (Datura stramonium L.) growing in the vicinity of the diseased potatoes. Identity of the leaflet stunt disease as ZC remains speculative, however.

The visual characteristics of BLOs in TEM of phloem tissue of ZC-infected plants were highly similar to those reported for other BLO-caused diseases including huanglongbing of citrus (3), strawberry marginal chlorosis (42), and basses richesses of sugar beet (9). Although not specifically identified, they are likely the liberibacter detected by DNA amplification assays. A triple-layered ultrastructure that includes the bacterial outer wall membrane and the inner cytoplasmic membrane observed in TEM of citrus-infecting liberibacter (3) was also evident in some of our electron micrographs (e.g., Fig. 6B). Although not definitive, this feature is consistent with the identification of the potato BLO as ' $\mathrm{Ca}$. $\mathrm{L}$. solanacearum'

Graft- and psyllid-inoculated potato and tomato plants were positive in PCR assays using either of the primer sets specific for the potato/tomato-associated liberibacter. Our PCR product sequences, fragments of the 16S rRNA gene, were homologous to $16 \mathrm{~S}$ rRNA sequences of liberibacter in potato and tomato in both New Zealand and California. Being unculturable, liberibacters are identified, detected, and classified largely on the basis of molecular signatures, particularly that of the 16S rRNA gene. While this approach has been invaluable in circumscribing species in Candidatus genera such as Liberibacter and Phytoplasma, caution in overinterpretation is warranted as there is some evidence that analyses of the 16S rRNA gene sequences may underperform in phylogenetic analysis at lower taxonomic levels among some groups of bacteria (27). Nevertheless, the $16 \mathrm{~S}$ rRNA sequence data of the potato liberibacter place it firmly in the ' $\mathrm{Ca}$.
Liberibacter' genus and with sufficient differences from the citrus-associated strains to warrant separate species status (Fig. 7), named ' $\mathrm{Ca}$. L. solanacearum' by Liefting et al. (23).

The two base pair difference we detected among the liberibacter amplicons from potato is suggestive of a base substitution mutation at complementary positions within a loop structure of the $16 \mathrm{~S}$ rRNA molecule. Although sequence divergence among separate copies of ribosomal operons within a single genome is known to occur (24), the sequence divergence in the potato-infecting liberibacter probably represents the existence of different strains because there were no base ambiguities at the substitution sites in any of the individual sequence readouts. Because the twobase polymorphism in the 16S rRNA gene among strains is only a minor difference, a common origin of the bacterium is likely.

The 33 geographically and host diverse samples of liberibacter from solanaceous hosts, obtained from greenhouse and field environments, together with liberibacter 16S rRNA gene sequences from GenBank, provided the basis for phylogenetic analyses (Fig. 7). The analysis clearly differen-

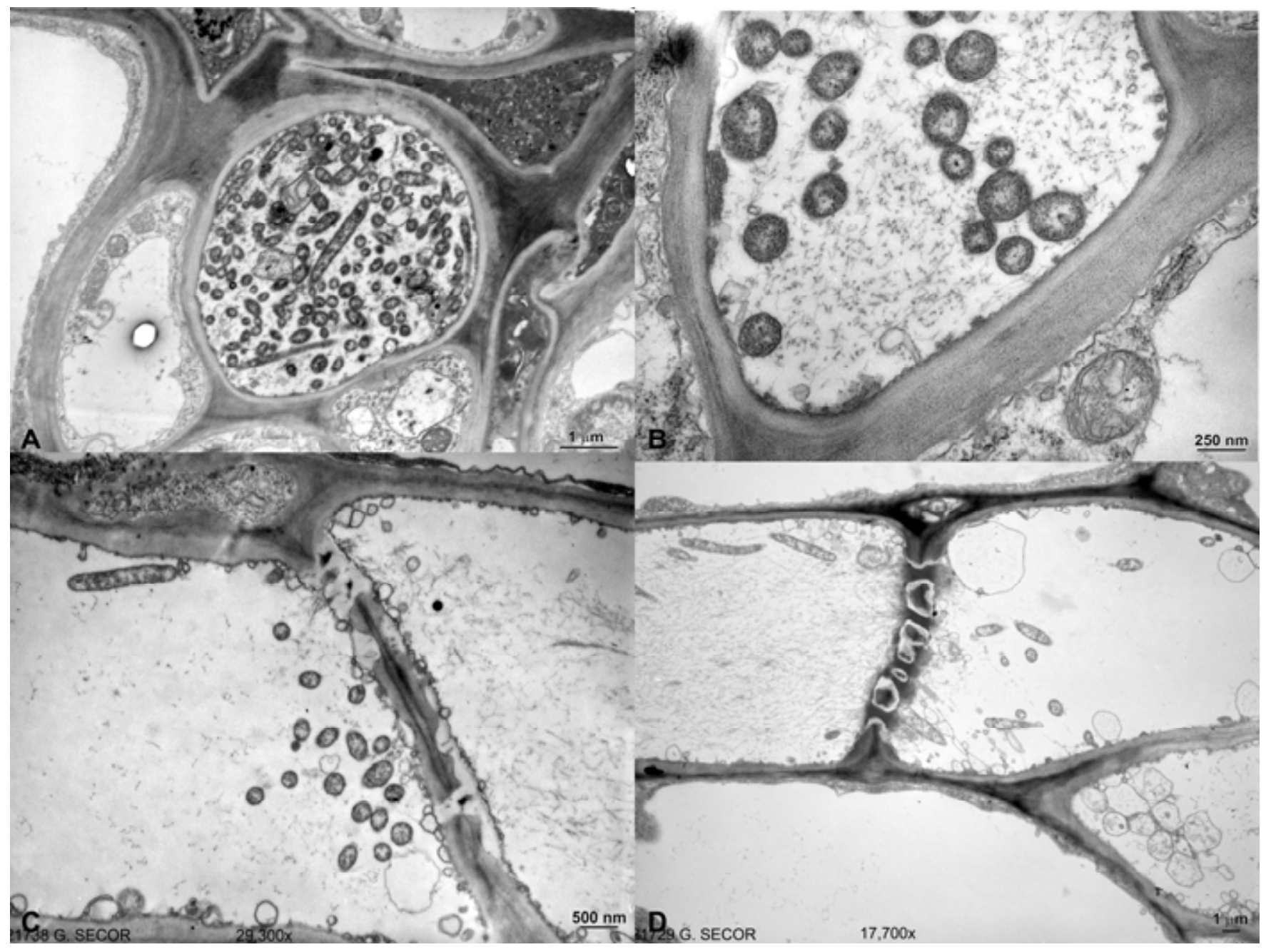

Fig. 6. Transmission electron micrographs of bacteria-like organisms in petiole phloem vessels of tomato plants A and B, grafted with zebra chip-diseased potato scion, and $\mathbf{C}$ and $\mathbf{D}$, infested with psyllids transferred from a zebra chip-diseased potato plant. 
tiated the solanaceous-associated liberibacter from citrus-associated strains as different taxonomic clades. Furthermore, the solanaceous-associated liberibacters were taxonomically more nearly similar to ' $\mathrm{Ca}$.
L. asiaticus' than to ' $\mathrm{Ca}$. L. africanus' and ' $C a$. L. americanus'. We were also able define a subtle difference in rRNA gene sequence among liberibacters from potato samples, but sequence type was not clearly correlated with a particular geographic origin as both strain types occurred among ZC samples from Texas.

Despite an earlier report that internal tuber necrosis is caused by psyllid feeding
98

Potato. Pearsall, Texas

Ca.L.psyllaurous.EU812556

Potato. Olton, Texas

Potato. Asturias, Guatemala

Ca.L.psyllaurous.EU812559

Potato. Pearsall, Texas

Ca.L.psyllaurous.EU812557

Potato. Pearsall, Texas

C.Li.asiaticus.EU265646

[C.Li.asiaticus.DQ432003isolate

C.Li.asiaticus.EU130555.F18Pol

C.Li.asiaticus.EU130554.F17Pal

C.Li.asiaticus.DQ157274

C.Li.asiaticus.DQ157273

C.Li.asiaticus.EU130553.F16Nas

C.Li.asiaticus.DQ471901.Brazil

C.Li.asiaticus.DQ471900.USA

C.Li.asiaticus.EU224393.GFBSe

99 C.Li.asiaticus.AY919311

C.Li.asiaticus.DQ432004.Chongq

C.Li.asiaticus.DQ431997.Guangx

C.Li.africanus subsp.capensis

100 C.Li.americanus.AY742824

C.Liberibacter.sp.AY919312.LSg

0.01

Sinorhizobium arboris.AM181752

sC2

Ca. Lib. asiaticus

\section{C2 Substitutions}

$T$ instead of $G$ at $103 \mathrm{bp}$

T instead of $C$ at $472 \mathrm{bp}$

Fig. 7. Phylogenetic tree depicting taxonomic position of zebra chip-associated 'Candidatus Liberibacter solanacearum' based on sequence of $16 \mathrm{~S}$ ribosomal gene fragment. The neighbor-joining method with 1,000 replicates was used. $\mathrm{sC} 1$ and $\mathrm{sC} 2$ designate subclades of liberibacter from solanaceous hosts. Scale bar unit indicates number of nucleotide substitutions per site. Sinorhizobium arboris is the out-group. 
(39), ZC appears to be a disease of relatively recent appearance (and certainly of only recent economic significance) and distinct from PY. While foliage symptoms of PY are often indistinguishable from ZC in the field, PY does not result in the same tuber problem for the processing and fresh market industry as ZC has become (G. A. Secor, unpublished). PY is principally described as a foliar disease that causes serious yield loss and a preponderance of small and misshapen tubers, but not internal tuber necrosis (2). PY was first described in the United States in 1928 (31) and occurs regularly in the southern potato growing states up to the present time. The discovery of the association of ' $\mathrm{Ca}$. L. solanacearum' with ZC is intriguing, therefore, because it is psyllid transmitted, as is the PY disease-associated phytoplasma. Hansen et al. (11) attributed PY to ' $\mathrm{Ca}$. L. psyllaurous', but unfortunately did not discuss symptomology of their "psyllid yellows" disease nor distinguish it from ZC. In our studies, we also sampled two potato plants with purported psyllid yellow symptoms, but these tested negative in PCR for liberibacter and we were unable to transfer disease to greenhouse-grown potato by either grafting or psyllid feeding (data not shown). However, because the $16 \mathrm{~S}$ rRNA sequence of ' $\mathrm{Ca}$. L. psyllaurous' is identical to the $16 \mathrm{~S}$ sequence of 'Ca. L. solanacearum' associated with ZC in both New Zealand and the United States, it seems likely that the two names are synonymous. We adopted the specific epithet 'solanacearum' in this study because it is validly published (23), whereas ' $\mathrm{Ca}$. L. psyllaurous' (11) is not according to Rule 28b of the Code of Nomenclature for Bacteria (http://www.ncbi.nlm.nih.gov/ books/bv.fcgi?rid=icnb), even though 'Candidatus' genera, sensu stricto, are not covered under the code. The possibility that PY and $\mathrm{ZC}$ are different manifestations of the same disease cannot be discounted. Could induction of tuber symptoms in liberibacter-infected plants (i.e., those with the PY disease) result from environmental factors, presence of different liberibacter pathovars, or co-infection with a secondary pathogenic microorganism? Only a comparative study of the etiology of PY and ZC on potato will resolve the conundrum.

\section{ACKNOWLEDGMENTS}

This work was supported in part by the grower funded Zebra Chip Steering Committee and from funds provided through a Specific Cooperative Agreement with the USDA Molecular Plant Pathology Laboratory. We thank Judy Rengifo, Pamela Ross, and Jane Gourley for excellent technical assistance in the lab, Tom Freeman and Jayma Moore for electron microscope work, Russell Benz for technical greenhouse assistance, Pat Lummus for entomological advice and psyllid collections, and Sclarczyk Seed Farms for minitubers. We also thank and acknowledge the many people who collected and sent zebra chip samples to us.
LITERATURE CITED

1. Abad, J. A., Bandla, M., French-Monar, R. D., Liefting, L. W., and Clover, G. R. G. 2009. First report of the detection of 'Candidatus Liberibacter' species in zebra chip diseaseinfected potato plants in the United States. Plant Dis. 93:108.

2. Arslan, A., Bessey, P. M., Matsuda, K., and Oebker, N. F. 1985. Physiological effects of psyllid (Paratrioza cockerelli) on potato. Am. Potato J. 62:9-22.

3. Bove, J. M. 2006. Huanglongbing: A destructive, newly-emerging century-old disease of citrus. J. Plant Pathol. 88:7-37.

4. Cadena-Hinojosa, M. A. 1999. Potato purple top in Mexico: III. Effects of plant spacing and insecticide application. Rev. Mex. Fitopatol. 17:91-96

5. Carter, W. 1939. Injuries to plants caused by insect toxins. Bot. Rev. 5:273-326.

6. Cranshaw, W. S. 2001. Psyllid yellows. Pages 73-74 in: Compendium of Potato Diseases, 2nd ed. W. R. Stevenson, R. Loria, G. D. Franc, and D. P. Weingartner, eds. American Phytopathological Society, St. Paul, MN.

7. Crosslin, J. M., Munyaneza, J. E., Jensen, A. S., and Hamm, P. B. 2005. Association of beet leafhopper (Hemiptera:Cicadellidae) with a clover proliferation group phytoplasma in the Columbia Basin of Washington and Oregon. J. Econ. Entomol. 98:279-283.

8. De Boer, S. H., Secor, G., Li, X., Gourley, J., Ross, P., and Rivera, V. 2007. Preliminary characterization of the etiologic agent causing zebra chip symptoms in potato. In: New and old pathogens of potato in changing climate. Proc. EAPR Pathology Section, Hattula, Finland. A. Hannukkala and M. Segerstedt, eds. Agrifood Res. Working Pap. 142:28.

9. Gatineau, F., Jacob, N., Vautrin, S., Larrue, J., Lherminier, J., Richard-Molard, M., and Boudon-Padieu, E. 2002. Association with syndrome "basses richesses" of sugar beet of a phytoplasma and a bacterium-like organism transmitted by a Pentastiridius sp. Phytopathology 92:384-392.

10. Goolsby, J. A., Adamcyk, J., Bextine, B., Lin, D., Munyaneza, J. E., and Bester, G. 2007. Development of an IPM program for management of the potato psyllid to reduce incidence of zebra chip disorder in potatoes. Subtrop. Plant Sci. 59:85-94.

11. Hansen, A. K., Trumble, J. T., Stouthamer, R., and Paine, T. D. 2008. New huanglongbing (HLB) Candidatus species, "Ca. Liberibacter psyllarous" found to infect tomato and potato is vectored by the psyllid Bactericera cockerelli. Appl. Environ. Microbiol. 73:75317535.

12. Jagoueix, S., Bove, J. M., and Garnier, M. 1994. The phloem-limited bacterium of greening disease of citrus is a member of the $\alpha$ subdivision of the Proteobacteria. J. Syst. Bacteriol. 44:379-386.

13. Klein, M., Zimmerman-Gries, S., and Sneh, B. 1976. Association of a bacterial-like organism with a new potato disease. Phytopathology 66:564-569.

14. Kumar, V., Grama, A., Gupta, A., and Karypis, G. 1994. Introduction to parallel computing: Design and analysis of algorithms. Benjamin/Cummings Publ. Co., Redwood City, CA.

15. Lee, I.-M., Bottner, K. D., Munyaneza, J. E., Secor, G. A., and Gudmestad, N. C. 2004. Clover proliferation group (16SrVI) subgroup A (16SrVI-A) phytoplasma is a probable causal agent of potato purple top disease in Washington and Oregon. Plant Dis. 88:429.

16. Lee, I.-M., Bottner, K. D., Secor, G., and Rivera-Varas, V. 2006. 'Candidatus Phytoplasma americanum', a phytoplasma associated with a potato purple top wilt disease complex. Int. J. Syst. Evol. Microbiol. 56:15931597.
17. Lee, I.-M., Gundersen-Rindal, D. E., Davis, R. E., and Bartoszyk, I. M. 1998. Revised classification scheme of phytoplasmas based on RFLP analyses of $16 \mathrm{~S}$ rRNA and ribosomal protein gene sequences. Int. J. Syst. Bacteriol. 48:1152-1169.

18. Leyva-Lopez, N. E., Ochoa-Sanchez, J. C., Leal-Klevezas, D. S., and Martinez-Soriano, J. P. 2002. Multiple phytoplasmas associated with potato diseases in Mexico. Can. J. Microbiol. 48:1062-1068.

19. Li, X., De Boer, S. H., Secor, G., Gourley, J., Ross, P., and Rivera, V. 2008. Are bacteria the causal agent of the zebra chip disease of potato? (Abstr.) Can. J. Plant Pathol. 30:377.

20. Liefting, L. W., Perez-Egusquiza, Z. C., Clover, G. R. G., and Anderson, J. A. D. 2008. A new 'Candidatus Liberibacter' species in Solanum tuberosum in New Zealand. Plant Dis. 92:1474.

21. Liefting, L. W., Sutherland, P. W., Ward, L. I., Paice, K. L., Weir, B. S., and Clover, G. R. G. 2009. A new 'Candidatus Liberibacter' species associated with diseases of Solanaceous crops. Plant Dis. 93:208-214.

22. Liefting, L. W., Ward, L. I., Shiller, J. B., and Clover, G. R. G. 2008. A new 'Candidatus Liberibacter' species in Solanum betaceum (tamarillo) and Physalis peruviana (cape gooseberry) in New Zealand. Plant Dis. 92:1588.

23. Liefting, L. W., Weir, B. S., Pennycook, S. R., and Clover, G. R. G. 2008. 'Candidatus Liberibacter solanacearum', a liberibacter associated with plants in the family Solanaceae. Int. J. Syst. Evol. Microbiol. In press.

24. Lopez-Lopez, A., Benlloch, S., Bonfa, M. Rodriguez-Valera, F., and Mira, A. 2007. Intergenomic 16S rDNA divergence in Haloarcula marismortui is an adaptation to different temperatures. J. Mol. Evol. 65:687-696.

25. Munyaneza, J. E., Crosslin, J. M., and Upton, J. E. 2007. Association of Bactericera cockerelli (Homoptera Psyllidae) with "zebra chip", a new potato disease in southwestern United States and Mexico. J. Econ. Entomol. 100:656-663.

26. Munyaneza, J. E., Goolsby, J. A., Crosslin, J. M., and Upton, J. E. 2007. Further evidence that zebra chip potato disease in the lower Rio Grande Valley of Texas is associated with $\mathrm{Bac}$ tericera cockerelli. Subtrop. Plant Sci. 59:3037.

27. Naum, M., Brown, E. W., and Mason-Gamer, R. J. 2008. Is 16S rDNA a reliable phylogenetic marker to characterize relationships below the family level in the Enterobacteriaceae? J. Mol. Evol. 66:630-642.

28. Page, R. D. M. 1996. TREEVIEW: An application to display phylogenetic trees on personal computers. Comp. Appl. Biosci. 12:357358.

29. Peres, L. E. P., Carvalho, R. F., Zsögön, A., Bermúdez-Zambrano, O. D., Robles, W. G. R., and Tavares, S. 2005. Grafting of tomato mutants onto potato rootstocks: An approach to study leaf-derived signalling on tuberization. Plant Sci. 169:680-688.

30. Rascoe, J., Berg, M., Melcher, U., Mitchell, F. L., Bruton, B. D., Pair, S. D., and Fletcher, J. 2003. Identification, phylogenetic analysis, and biological characterization of Serratia marcescens strains causing cucurbit yellow vine disease. Phytopathology 93:1233-1239.

31. Richards, B. L. 1928. A new and destructive disease of the potato in Utah and its relation to the potato psylla. Phytopathology 18:140-141.

32. Schneider, B., Ahrens, U., Kirkpatrick, B. C., and Seemuller, E. 1993. Classification of plant-pathogenic mycoplasma-like organisms using restriction-site analysis of PCRamplified 16S rDNA. J. Gen. Microbiol. 139:519-527.

33. Secor, G. A., Lee, I. M., Bottner, K. D., Rivera 
V. V., and Gudmestad, N. C. 2005. A new potato disease causing extensive discoloration of processed crisps associated with a phytoplasma infection. Pages 117-118 in: Proc. 16th Trienn. Conf. EAPR, Bilbao, Basque Country.

34. Secor, G. A., Lee, I.-M., Bottner, K. D., Rivera-Varas, V., and Gudmestad, N. C. 2006. First report of a defect of processing potatoes in Texas and Nebraska associated with a new phytoplasma. Plant Dis. 90:377.

35. Secor, G. A., and Rivera, V. V. 2004. Emerging diseases of cultivated potato and their impact on Latin America. Rev. Latinoamericana Papa (Suppl.) 1:1-8

36. Secor, G. A., Rivera, V., Rengifo, J., De Boer, S. H., Lee, I.-M., and Gudmestad, N. C. 2008. Zebra chip: A new disease of potato. (Abstr.)
Am. J. Pot. Res. 85:29.

37. Semetey, O., Gatineau, F., Bressan, A., and Boudon-Padieu, E. 2007. Characterization of a $\gamma-3$ proteobacteria responsible for the syndrome "basses richesses" of sugar beet transmitted by Pentastiridius sp. (Hemiptera, Cixiidae). Phytopathology 97:72-78.

38. Slack, S. A. 2001. Diseases caused by phytoplasmas. Pages 56-57 in: Compendium of Potato Diseases, 2nd ed. W. A. Stevenson, R. Loria, G. D. Franc, and D. P. Weingartner, eds. American Phytopathological Society, St. Paul, $\mathrm{MN}$.

39. Snyder, W. C., Thomas, H. E., and Fairchild, S. J. 1946. A type of internal necrosis of the potato tuber caused by psyllids. Phytopathology 36:480-481.

40. Teixeira, D. C., Saillard, C., Eveillard, J. L. D., da Costa, P. I., Ayres, A. J., and Bove, J. 2005. 'Candidatus Liberibacter americanus' associated with citrus huanglongbing (greening disease) in Sao Paulo State, Brazil. Int. J. Syst. Evol. Microbiol. 55:1857-1862.

41. Thompson, J. D., Gibson, T. J., Plewniak, F., Jeanmougin, F., and Higgins, D. G. 1997. The CLUSTAL_X windows interface: Flexible strategies for multiple sequence alignmen aided by quality analysis tools. Nucleic Acids Res. 25:4876-4882.

42. Zreik, L., Bove, J. M., and Garnier, M. 1998. Phylogenetic characterization of the bacterium-like organism associated with marginal chlorosis of strawberry and proposition of a candidates taxon for the organism, 'Candidatus Phlomobacter fragariae'. Int. J. Syst. Bacteriol. 48:257-261. 